\title{
95. Notes on the Distribution of the Freshwater Pearl Mussel, Margaritana margaritifera in Japan.
}

By Yaichiro OKADA and Kazuo KoBA. Zoological Institute, Tokyo Higher Normal School.

(Comm. by A. OKA, M.I.A., July 12, 1933.)

The Holarctic freshwater pearl mussel Margaritana margaritifera (Linné), which is generally distributed in the northern parts of Europe, Siberia and North America, also occurs in Japan. The geographical distribution of this species in Japan is very interesting, as we have indicated in three short papers ${ }^{1)}$ published in Japanese. This species is generally distributed in the northern parts of Japan, in Sakhalin, Kuriles, Hokkaidô and parts of Japan proper. But it seems to become gradually scarce toward the south in Japan.

In the accounts of the distribution of the present species by previous authors, the southernmost limit in the world is given as about $35^{\circ} \mathrm{N}$. latitude (northern part of Arizona, U.S.A. by Walker). It is very interesting, therefore, that we found it farther south in Japan, at $34^{\circ} 17^{\prime} \mathrm{N}$. latitude. ${ }^{2)}$

In Sakhalin and Hokkaidô, this species is found abundantly, nearly almost everywhere in rivers and streams, while in Japan proper only a few localities are mentioned by previous authors.

One of the authors (Koba), in staying at Akan-ko, a very famous mountain lake in the central part of Hokkaidô, found this mussel in large numbers in a rather shallow place of the river between Panke and Akan-ko lakes but not in the lakes themselves. It buries nearly two-thirds of the body obliquely at an angle of $40^{\circ}$ to $80^{\circ}$ into the sand and gravel, directing its ventral side against the current of the river.

A further observation of interest was made by Koba when he explored the northern Kuriles in the beginning of the summer of 1931 . He found one specimen of Margaritana margaritifera in one of the

1) Okada, Y. and Koba, K., 1931. A preliminary note on the distribution of Margaritana margaritifera in Japan. Dobutsugaku Zasshi, 43, 312-319:-1932. Notes on the distribution of Margaritana margaritifera. Kagaku, 2, 108-112:-1932. On some localities of Margaritana margaritifera in Japan. Venus, 3, 106-108.

2) Ono River at Kamagahara, Sakagami-mura, Yamaguchi-Ken (T. Kawamoto, 1928.) 


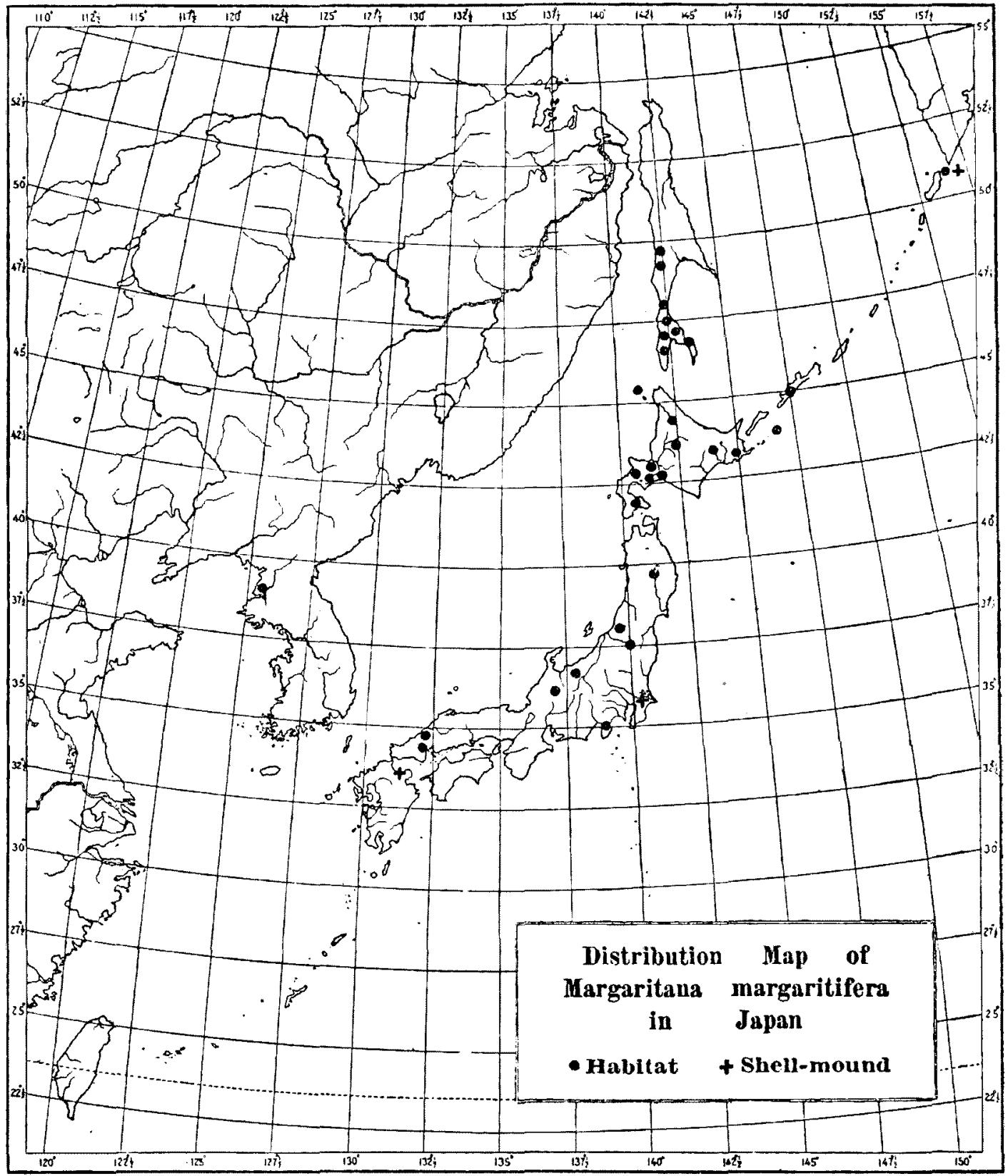

shell-mounds of Bettobu, Shimushir Island together with several kinds of marine littoral shells ${ }^{11}$ such as Fusitriton oregonensis (Redfield), Buccinum chishimanum Pilsbry, Nucellalima freycineti (Deshayes), Pododesmus macrochismus (Deshayes), Volsella modiola (Linné), Cardium californiense Deshayes and Serripes laperousii (Deshayes).

These shells were apparently used as food by the former inhabitants of this island. We suppose that they took only the littoral and fresh-

1) The identification of these marine shells was made by $T$. Kuroda, of the Geological Institute, Kyoto Imperial University to whom we pay thanks. 
No. 7.] Notes on the Distribution of the Freshwater Pearl Mussel.

water mollusks because they lacked means of fishery suitable for venturing into the open sea.

Furthermore Ohyama (1929) found specimens of this species from a shell-mound in Chiba-Ken, Honshû, and Higuchi (1931) in Ôita-Ken, northern Kyûshû.

\section{Literature cited.}

Higuchi, K., 1931: Ueber die neu gefunden Muschelhaufen Mori unweit von Takada, Prov. Bungo, Kyushu. Zeits. f. Praehistorie, 3, 18-50.

Kawamoto, T., 1928a: New locality of Margaritana margaritifera (Linné). Dobutsugaku Zasshi, 40, 96.

Kawamoto, T., 1928b: On Margaritana margaritifera (Linné) from Yamaguchi Prefecture. Venus, 1, 15-18.

Ohyama, K. and Sugiyama, S. etc., 1929: Ausgrabungsberichts über die Muschelhaufengruppe Kaizuka beim Dorf Yoshibumi, Provinz Chiba. Zeits. f. Praehistorie, 1, $349-371$.

Walker, B., 1910: The distribution of Margaritana margaritifera (Linné) in North America. Proc. Malac. Soc. of London, 9, 126-145. 